\title{
EVAPOTRANSPIRATION AND PHYSIOLOGICAL RESPONSES TO WATER STRESS OF SEVERAL PASTURE AND CROP SPECIES
}

\author{
J. P. KerR and H. G. McPherson
}

Plant Physiology Division, DSIR, Palmerston North

\begin{abstract}
A bstract
The effect of water on pasture and crop yield is determined by many factors in the soil-plant-atmosphere system. Over recent years, Plant Physiology Division has been examining the system to better understand the principles to be applied in effectively manag!ng pasture and crops under dryland and irrigation and to find criteria which could be used in breeding plants better adapted to dry conditions. The evapotranspiration of pastures and crops, the influence of pastures and crops on their water loss through leaf cover and stomatal bchaviour, some of the consequences of watcr stress on leaf growth, as well as soil evaporation and drainage losses, are discussed.
\end{abstract}

\section{INTRODUCTION}

PASTURE and crop production in New Zealand is frequently limited by drought - i.e., "any period when water deficiency, either acute or chronic, affects plant growth and decisions on what to plant and how to grow it" (Viets, 1971). Dry spells can have serious consequences on an agriculture based on high pasture production per hectare. The only really effective way of reducing drought losses is to irrigate or increase rainfall. However, for many farms irrigation is not feasible, prospects for rainmaking are poor, so we need to learn how to make the best use of the rainfall that is received.

There are three components making up the system which determines pasture and crop water use and production: tha soil, the plant, and the atmosphere. Water stored in the soil moves through the plant to the atmosphere. Energy required to evaporate water from the leaf is received either as radiation or from dry air moving over the pasture.

There is a delicate water balance within the plant because the quantity of water lost by transpiration is large compared with the quantity of water present in the plant at any time. A rapidly growing pasture loses its own wet weight in water every few hours. 
Key plant physiological processes differ in their sensitivity to plant water status and their responses change appreciably throughout the growing season. The timing of drought, its severity, and duration all influence the extent of the reduction in pasture yield when water is in short supply.

The soil-plant-atmosphere system is complex and the research philosophy that has been adopted at Plant Physiology Division over the past 7 or 8 years has been based on the belief that to manipulate the system it is necessary to understand it better. The Division is looking for principles to be applied in effectively managing dryland and irrigated farms and for criteria to use in breeding plants better adapted to dry conditions. This paper discusses research results relating to some components of the system.

\section{WATER LOSS FROM PASTURES}

\section{How Much Water do Pastures and Crops Use?}

The first objective was to measure the quantity of water used (i.e., evapotranspiration) by pastures and crops. Evapotranspiration (ET) includes transpiration of water by leaves and evaporation of free water from the surface of soils and plants (e.g., rain or dew). This was measured using the energy balance method (Tanner, 1960; Talbot and Kerr, 1972) which has an accuracy

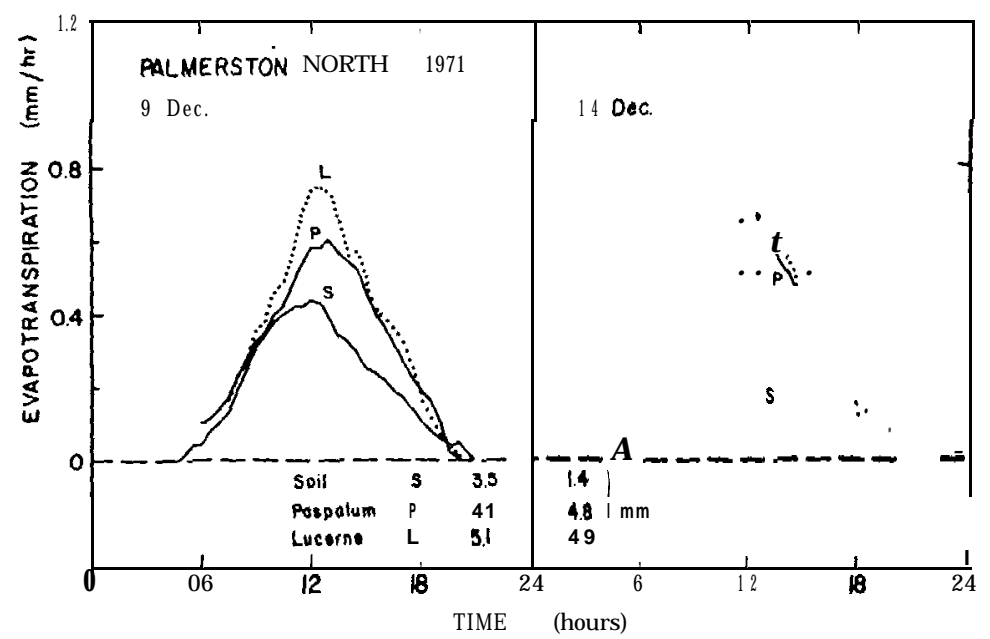

FiG. 1: Daily patterns of bare soil evaporation and evapotranspiration from lucerne and paspalum $\mathrm{w}$ ards. 
of $\pm 10 \%$. Measurements were made over flat fields at least 1 ha in area, located on Manawatu fine sandy loam. All pastures and crops were well watered.

The daily evapotranspiration patterns for paspalum, lucerne, and bare soil in Fig. 1 illustrate the technique. The leafy paspalum and lucerne swards (LAI exceeds 3.0) transpired rapidly with a water use of 4.7 to $5.2 \mathrm{~mm} /$ day, whereas bare soil evapotranspiration fell from $3.4 \mathrm{~mm} /$ day to $1.3 \mathrm{~mm} / \mathrm{day}$ as the soil surface dried.

Evapotranspiration measured on 31 days during late springsummer $1971-2$ averaged $4.6 \mathrm{~mm} /$ day for lucerne and $4.1 \mathrm{~mm} /$ day for paspalum. Maximum rates of $6.5 \mathrm{~mm} /$ day and $5.7 \mathrm{~mm} /$ day were recorded for lucerne and paspalum, respectively. On a 100 ha farm pasture evapotranspiration can approach 800 million litres each year (i.e., equivalent to $800 \mathrm{~mm}$ rain).

\section{What is the Primary factor Controliting Pasture \\ WATER USE?}

The weather is a primary factor controlling the evapotranspiration from any pasture or crop in which the soil is well covered by the leaves and soil water is adequate. The maximum daily water use $(\mathrm{ET},,$,$) of an actively growing pasture can be predicted$ quite accurately from daily measurements of air temperature and solar or net radiation. The Priestley and Taylor (1972) equation can be used:

$$
\mathrm{ET}_{,,,}=1.26[\mathrm{~s} /(\mathrm{s}+\gamma)] \mathrm{RN}
$$

where $s /(s+\gamma)$ is calculated from the daily mean temperatures and net radiation, and $R_{N}$ is either measured directly or estimated from solar radiation measurements. Daily water use can be predicted within 15 to $20 \%$ on a daily basis and $10 \%$ on a weekly basis (Clothier, 1977).

The effects of season and weather on the evapotranspiration of several pastures and crops have been examined at Palmerston North. Typical daily crop water use changes from $4.3 \mathrm{~mm} / \mathrm{day}$ in January to $0.6 \mathrm{~mm} /$ day in June.

The species effects on evapotranspiration rates are relatively small compared with the weather effects. When soil water supply is adequate, and leaf cover is complete, comparative ET measurements over paspalum and lucerne on 34 days during the period October 1971 through March 1972 show that the evapotranspiration of paspalum was about $12 \%$ below that of lucerne (Kerr et ul., 1973). 
In practice ET is also influenced by pasture and soi! factors such as the area of transpiring leaf, the opening of leaf stomata and the availability of soil water. Both transpiration and soil evaporation are restricted when soil water supply is sub-optimal. ET will be reduced when about $50 \%$ or more available soil water has been used.

\section{Can Pastures Influence Water Loss?}

Under well-watered conditions, the effects of the pasture on its evapotranspiration rate are secondary to those of the weather. Nevertheless, the effects of plant cover and stomata1 behaviour can be significant, particularly as the soil dries.

\section{Pasture and Crop Cover}

For row crops, ET increases during early growth until maximum values are reached when LAI exceeds 3.0 (Monteith et al., 1965; Ritchie and Burnett, 197 1). Pastures will probably behave similarly, so that when LAI is below 3.0 transpiration will be lowered and ET will be determined increasingly by soil surface factors.

Soil evaporation removes water from shallow depths and the rates fall rapidly as the soil surface dries, whereas transpiring plants extract water from deeper in the soil profile. Bare soil evaporation can be calculated using the procedure of Black et al. (1969).

$$
E_{\mathrm{s}}=C\left[t^{1 / 2}-(t-1)^{1 / 2}\right]
$$

where $t$ is the number of days since the last significant rainfall, and $\mathrm{C}$ is a physical constant for the particular soil.

The increased water use when plants are present can be demonstrated by comparing paspalum evapotranspiration with evaporation from bare soil (Kerr, 1974). The paspalum used $144 \mathrm{~mm}$ water compared with $75 \mathrm{~mm}$ on the fallow. After allowing for drainage and run-off losses of $7.5 \mathrm{~mm}$, the fallow conserved $61.5 \mathrm{~mm}$ of water under the November 1971 rainfall pattern.

Further studies are required to define satisfactorily the relative importance of transpiration and soil evaporation for pastures with a partial leaf cover (i.e., LAI less than 3.0). 


\section{Stomatal Control}

The leaves of pasture species are covered by a relatively impermeable waxy cuticle. However, small stomata1 pores set in the epidermis allow $\mathrm{CO}_{2}$ to pass into the leaf where it is absorbed by the moist internal tissues and used in photosynthesis. Simultaneously, water vapour passes out through the stomata into the relatively dry air. These pores adjust their aperture to light, plant water status, $\mathrm{CO}_{2}$ concentration and temperature.

The stomata1 behaviour of paspalum and lucerne growing in the field was found to be different. Results are expressed as a resistance where low resistances indicate open stomata. The average stomata1 resistances of well lit individual leaves were 0.5 and $2.4 \mathrm{~s} / \mathrm{cm}$ for lucerne and paspalum, respectively. The behaviour of white clover stomata is similar to lucerne, and perennial ryegrass is intermediate between lucerne and paspalum.

To determine the importance of the stomata in the pasture canopy as a whole, stomata1 resistances measured on individual leaves were compared with canopy resistances calculated from humidity gradients and pasture evapotranspiration rates. For several fine days during February and March, canopy resistances followed stomata1 resistances closely $(r=0.89)$. A change in leaf stomata1 resistance of $2 \mathrm{~s} / \mathrm{cm}$ resulted in a change in whole canopy resistance of approximately $1 \mathrm{~s} / \mathrm{cm}$ (Kerr et al., 1973). For this period the mean canopy resistance for paspalum (1.2 $\mathrm{s} / \mathrm{cm})$ was twice that of lucerne $(0.6 \mathrm{~s} / \mathrm{cm})$. However, measured evapotranspiration for the same period was only $20 \%$ lower for paspalum than for lucerne.

Differences in leaf stomata1 resistance between lucerne and paspalum were quite large, but differences in water use were relatively small. Generally the stomata1 resistance effects will be greatest when the canopy is incomplete and/or the soil is dry.

The effects on evapotranspiration of the aerodynamic roughness and solar radiation reflection characteristics of the pasture and crop have not been studied, but these effects are expected to be small. The more important effects of the timing and depth of soil water extraction by roots need further study.

\section{THE CONSEQUENCES OF REDUCED PLANT WATER CONTENT}

The large daily and seasonal fluctuations in water flow through the plant cause important changes in the leaf-water status (i.e., leaf-water potential). Typical changes in the leaf-water status for 
WATER STRESS IN PASTURE AND CROPS

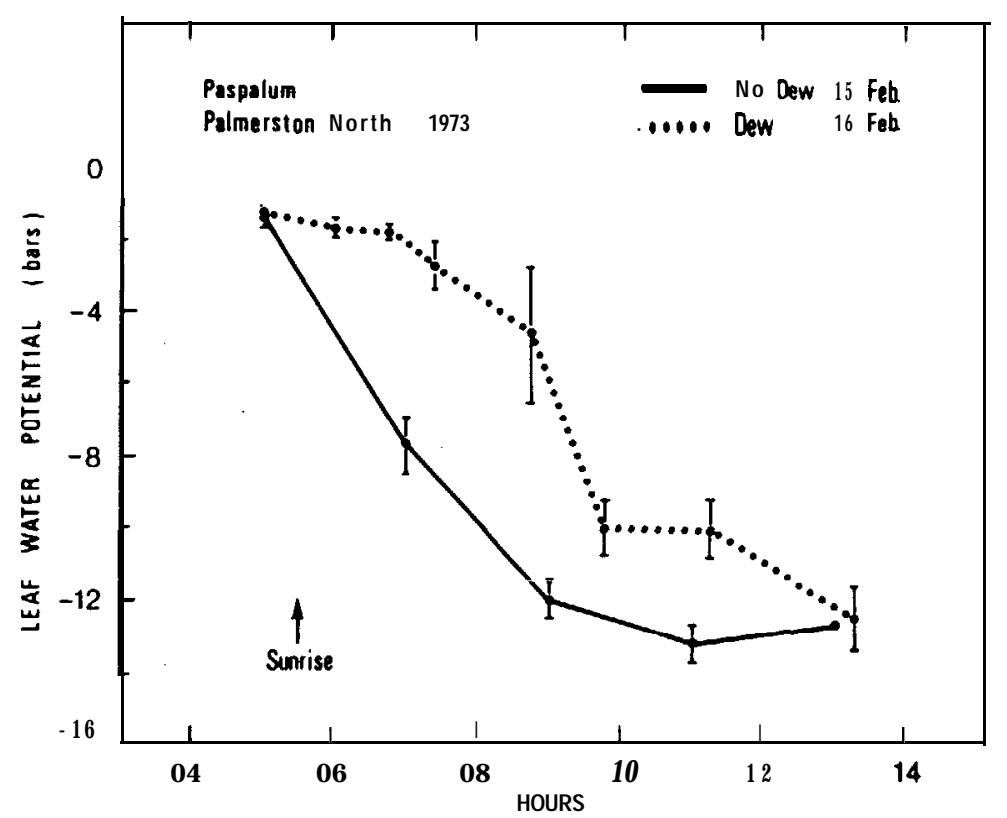

FIG. 2: Leaf-water potentials on a dew-free and dew morning. Vertical bars indicate SE of the means. (After Kerr and Beardsell, 1975.)

paspalum growing in the field are shown in Fig. 2. Dew will raise the daytime leaf-water status while it is present.

Comparison of leaf extension rates between plants growing in a well-watered soil with plants in a drying soil shows that leaf growth is sensitive to water availability. Controlled environment studies of Chu and McPherson (1977) illustrate this point. The day and night leaf-water potentials of the well-watered prairie grass did not change but potentials of the stressed plants slowly declined as the soil dried (Fig. 3). The leaf extension rate of the stressed plants declined rapidly as soon as the reductions in leaf-water potential became apparent. Leaf growth rates were slowed as soon as the effects of soil drying could be detected in the grass.

Recovery of Leaf Growth after Drought

How quickly can plants recover initial growth rates after drought lasting several days? In controlled environment experi-

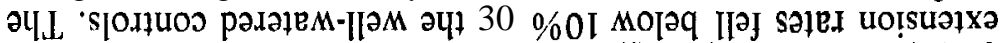
ments with prairie grass, the soil was allowed to dry until leaf: 


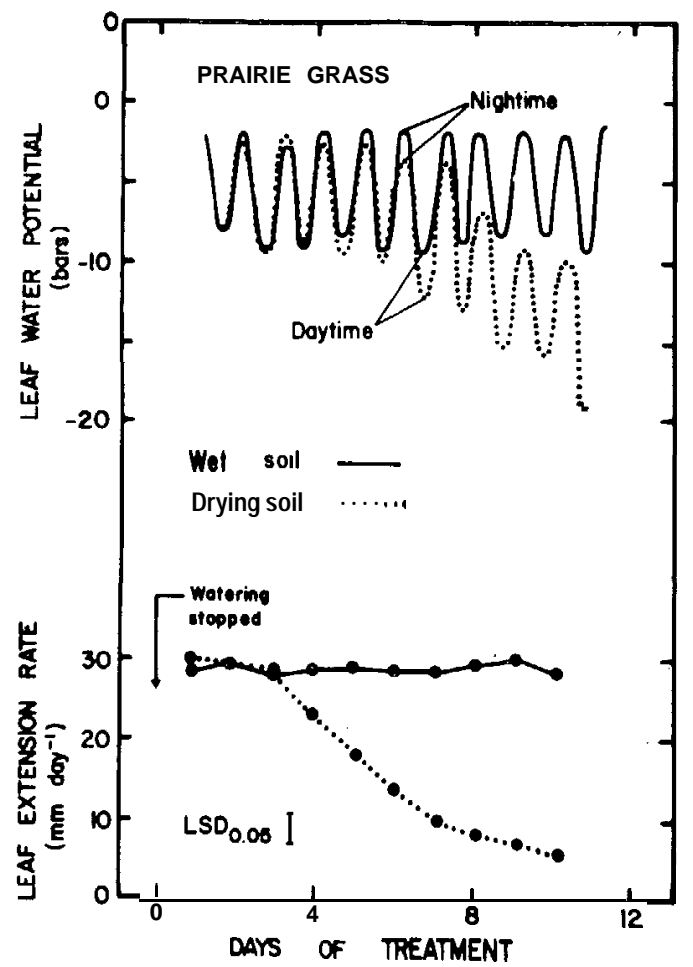

FIg. 3: Leaf-wafer potentials and daily leaf extension rates for prairie grass growing in w ell-watered and drying soils. (After $\mathrm{Ch} u$ and M CPherson, 1977.)

drought was applied to separate groups of plants for 1, 9 and 18 days and then rewatered. Leaf extension rates on all plants reached the initial "pre-drought" rates within 4 to 10 days of rewatering and continued at above-normal rates for several days. Dry matter and leaf area production measured $\mathbf{4 7}$ days after water was withheld showed that the plants effectively ceased vegetative growth during the drought period and then recommenced growth at normal rates as soon as the water was applied (A. Chu and H. G. McPherson, unpubl. data).

\section{BUDGETING WATER IN THE SOIL-PLANT SYSTEM}

If the soil water available to pastures and crops at any time is monitored sound decisions on when to apply irrigation water can be made. The same information can also be used to measure 
TABLE 1: INDIVIDUAL COMPONENTS OF THE WATER BALANCE FOR WINTER (MAY-OCT.) AND SUMMER (NOV.-FEB.) PERIODS AT PALMERSTON NORTH

30 -year average rainfalls are $518 \mathrm{~mm}$ for winter and $336 \mathrm{~mm}$ for summer

\begin{tabular}{|c|c|c|c|c|c|}
\hline & & \multirow{2}{*}{$\begin{array}{c}\text { Rainfall } \\
(\mathrm{mm})\end{array}$} & \multicolumn{2}{|c|}{$\begin{array}{c}\text { Ewapotranspiration } \\
(\mathrm{mm})\end{array}$} & \multirow{2}{*}{$\begin{array}{l}\text { Drainage } \\
(\mathrm{mm})\end{array}$} \\
\hline & & & Pasture & Crop & \\
\hline $\begin{array}{l}1974 \\
1975\end{array}$ & ("'n' & $\begin{array}{l}720 \\
585\end{array}$ & $\begin{array}{l}285 \\
285\end{array}$ & $\begin{array}{c}\text { O afs } \\
285 \\
285 \\
\text { Maize }\end{array}$ & $\begin{array}{l}428 \\
348\end{array}$ \\
\hline $\begin{array}{c}\text { Summer 1974-5: } \\
\text { Irrigated } \\
\text { Dryland }\end{array}$ & $\ldots$ & $\begin{array}{l}285^{*} \\
182\end{array}$ & $\stackrel{526}{-}$ & $\begin{array}{l}291 \\
241\end{array}$ & $\begin{array}{l}57 \\
20\end{array}$ \\
\hline
\end{tabular}

*Includes $182 \mathrm{~mm}$ rainfaii.

the effect of drought on pasture and crop production. Direct and continuous measurement of soil water is difficult. An alternative approach is to budget the soil water by measuring the inputs: rainfall and irrigation, and the outputs; evapotranspiration, drainage, and run-off.

Individual components of the soil water budgets for winter and summer pastures and crops are presented in Table 1. These data were collected by measuring rainfall and estimating both ET and drainage (Kerr and Clothier, 1975; Clothier, 1977). The ET estimates for pasture represent the maximum water use assuming a well-watered pasture with LAI above 3.0.

The data illustrate that in winter there is usually no difference in water use between pasture and crops, whereas in summer the lower water use of the crop with only partial leaf cover during establishment results in a considerable saving of water. The budgets are for a soil of $90 \mathrm{~cm}$ depth and an available water-holding capacity of $100 \mathrm{~mm}$.

These budgets can be used for irrigation scheduling given two further pieces of information - first, an estimate of the water storage capacity of the soil which takes account of the effective rooting depth of the pasture or crop being grown; secondly, an estimate of the quantity of water that can be removed from the soil before plant growth is affected.

\section{CONCLUSIONS}

Understanding the variable soil-plant-atmosphere system is helping to determine why soil water availability affects pasture 
yields. This approach promises to help in applying experimental results to other seasons, sites, species or cultivars.

The weather primarily determines ET under well-watered conditions so that ET can be estimated quite reliably from easily measured weather parameters. Because the effects of pasture on El' are of secondary importance, production per unit of water used will be highest in well-managed, high producing pasture>.

The water use of summer crops during establishment will be less than the water needs of adjacent pastures or lucerne with well-developed leaf canopies. Water use on well-watered pasture and crops will be similar when LAI exceeds 3.0.

Differences in leaf stomatal resistances between lucerne and paspalum were quite large, but differences in water use were small. The effects of stomata1 resistances are probably greatest when leaf canopy is incomplete and the soil is drying.

Leaf growth rates are slowed as soon as the effects of soil drying can be detected in the plant. For prairie grass, the leaf production lost during drought was proportional to the length of the drought period.

Budgets can be prepared giving the daily soil water status for a pasture or crop. These budgets can be used for scheduling the application of irrigation water.

\section{REFERENCES}

Black, T. A.; Gardner, W. R.; Thurtell, G. W., 1969. Soil Sci. Soc. A m. Proc., 33: 655-60.

Chu, A. C. P.; McPherson, H. G., 1977. A ust. J. Plant Physiol., 4: 331-7. Clothier, B. E., 1977. Ph.D. thesis, Soil Science Dept., Massey University, pp. 129.

Kerr, J. P., 1974. Proc. A gron. Soc. N.Z., 4: 30-3.

Kerr, I. P.; Beardsell, M. F., 1975. A gron. I., 67: 596-9.

Kerr, J. P.; Clothier, B. E., 1975. Proc. A gron. Soc, N.Z., 5: 49-53.

Kerr, J. P.; McPherson, H. G.; Talbot, j. S., 1973. Proc. 1st Aust. Conf. Heat \& M oss Transfer, Monash U., Melb. Sect 3: 1-8.

Monteith, J. L.; Szeicz. G.; Waggoner, P. E., 1965. I. appl. Ecol., 2: 345. Priestley, C. H. B.; Taylor, R. J., 1972. M on. W eather Rev., ZO 0: 81-92.

Ritchie, J. T.; Burnett. E., 1971. Agron. J., 63: 56-62.

Talbot, J. S.; Kerr, J. P., 1972. Proc. A gron. Soc. N.Z, 2: 111-26.

Tanner, C. B., 1960. Soil Sci. Soc. Am. Proc., 24: 1-9.

Viets, F. G., 1971. CSSA Spec. Pub. N 0. 2, Crop Sci. Soc. Am., Madison, pp. $57-76$. 